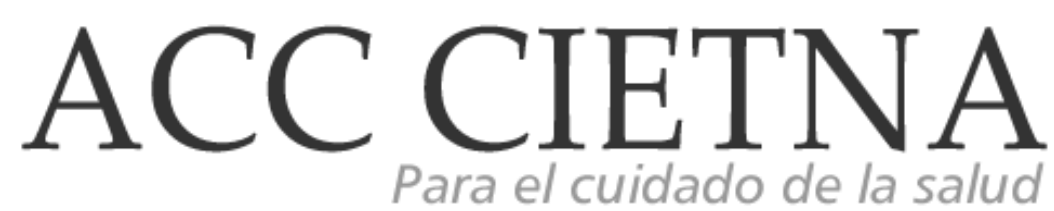

https://doi.org/10.35383/cietna.v2i1.167

EDITORIAL

\title{
EL RESPETO A LA DIGNIDAD HUMANA, BASE FUNDAMENTAL PARA DESARROLLAR EL CUIDADO
}

\section{Cervera Vallejos Mirtha Flor ${ }^{1}$}

\begin{tabular}{ll} 
INFORMACIÓN DEL ARTÍCULO & RESUMEN \\
\hline Historia del artículo: & La dignidad de la persona consiste en que cada individuo es único e \\
Recibido el 3 de marzo de 2015 & irrepetible y no puede transferir su propio ser a la función que hace. Por \\
Aceptado el 15 de mayo de 2015 & esta razón, el servicio al que está llamada la enfermera requiere una \\
& relación personal, de persona a persona y no de una cosa objeto a otra \\
\hline $\begin{array}{l}\text { Palabras claves: } \\
\text { Dignidad humana } \\
\text { Cuidado }\end{array}$ & $\begin{array}{l}\text { cosa objeto, pues, si es así, cabe el peligro que la persona vulnerable y } \\
\text { Respeto }\end{array}$ \\
& enferma ya sea hospitalizada o en una comunidad se le trate sin la \\
& dignidad debida.
\end{tabular}

El respeto a la dignidad humana es base fundamental para desarrollar el cuidado y protegerla en la conservación de la vida'. La acción de cuidar requiere del reconocimiento de la persona, especialmente si está enferma; implica personalizar, realizar acciones acorde con su realidad, defender su valor característico: "lo único", distinción propio de lo personal2.

En este sentido, la persona no es algo sino alguien, no cambia en el transcurso de la vida humana, mucho menos la enfermedad puede cambiar su esencia. Sin embargo, se comete el error de compararla, enumerarla en una determinada patología, reducirla a casos o cubrir coberturas y centrar las acciones en estos, quedando a veces a un segundo plano aquellas otras características que realzan su valor fundamental.

El cuidado no está acorde con la dignidad de la persona si se ejecuta sin sentido o por cumplir, cayendo en la rutina o al considerar solo la racionalidad técnica y el enfoque biomédico; es allí, donde la persona

${ }^{1}$ Doctora en Enfermería. Docente en la escuela de Enfermería de la Universidad Católica Santo Toribio de Mogrovejo. Chiclayo, Perú. Email: mcervera@usat.edu.pe 
pierde su valor y se convierte en un algo. El personalizar a través del cuidado, no obstante, implica un nivel más alto: el espíritu de la persona y la trascendencia de "alguien". Sobre todo cuando ese "alguien" cursa por una enfermedad de la índole que sea, necesita no sólo excelencia personal y profesional, sino también sensibilidad y conciencia del ser valioso, pues, "acercándose al cuerpo del enfermo, se acerca en realidad a su persona; la cual no es propiamente, "objeto" de la intervención sino "sujeto" de la misma"2

Lo mismo sucede, cuando una familia es atendida en una comunidad, la enfermera debe valorar no sólo el ciclo familiar, los riesgos del entorno, paquetes que la favorecen en su salud, dinámica familiar con genograma, apoyos institucionales entre otros, sino considerarla y atenderla en su integralidad, es decir escuchar todos sus problemas incluso la soledad en que vive. Por ello, la delicadeza con la cual cuidamos a la familia tiene que ser extrema con bases sólidas de ciencia, técnica y humanidad contribuyentes a tener un sólido sentido del valor de la vida, una profunda concepción de la muerte y ayudar a la familia en sus necesidades prioritarias.

Por otro lado, la espera de la persona en situación crítica, para definir su destino, luego de ser estabilizada hemodinámicamente, es un "tiempo de incertidumbre" más aún si la estadía es larga y la vive en un ambiente alejado de sus seres queridos y de su trabajo, con profesionales de salud que muchas veces la ven como "una enfermedad", reduciendo sus acciones a la entrega de turno, control de signos vitales, revisión del kárdex, administración del tratamiento prescrito, ejecución de procedimientos invasivos y elaboración de las notas de enfermería; generando una ciencia sin conciencia, donde la enfermera y la persona se tornan objetos del proceso saludenfermedad y cuando el alta se aproxima o es derivada a otro servicio se perdió la oportunidad de indagar más sobre ella y su contexto global.

Cuidar de una persona comprende un arte que abarca una profunda sabiduría antropológica, ética y estética ${ }^{3}$. Aspectos que fortalecerán las bases para la teoría y la práctica del cuidado ofreciendo nuevas orientaciones para adaptarla a las exigencias que reclaman la situación de salud de la población y de la sociedad en general. 
ABSTRACT

Keywords:

Human Disnity

Care

Respect
The dignity of the person is that each individual is unique and unrepeatable and can not transfer your own being to the function does. For this reason, the service is called the nurse requires a personal relationship, person to person and not a thing subject to anything other object, then, if so, there is a danger that vulnerable and sick either hospitalized or in a community be treated without due dignity.

The respect for human dignity is essential to develop care and protect the conservation of the live ${ }^{1}$. The act of caring requires recognition of the person, especially if you are sick; implies customization, take action in accordance with their reality, defend its characteristic value "all" what staff own distinction? ${ }^{2}$.

In this sense, the person is not something but someone, it does not change the course of human life, let alone the disease can change its essence. However, the mistake of comparing, list it in a given disease, or reducing it to cover cases coverage and focus action on these, leaving sometimes into the background those other features that enhance its fundamental value is committed.

The care is not consistent with the dignity of the person if executed without meaning or to fulfill, falling into a rut or consider only technical rationality and the biomedical approach; It is there where the person loses its value and becomes a something. The customization through care, however, involves a higher level: the spirit of the person and the importance of "someone". Especially when that "someone" carried by a disease of the nature that is, you need not only personal and professional excellence, but also sensitivity and awareness of being valuable, for "closer to the patient's body, it is about actually the person ; which is not proper, "object" of intervention but "subject" of the same"2

The same happens when a family is taken care of in a community, the nurse must assess not only the family cycle, environmental risks, packages that favor their health, family dynamics with genogram, institutional support, among others, but consider and attend to in its entirety, ie listen to all your problems even loneliness in which he lives. Therefore, the delicacy with which we take care of the family must be extremely solid foundations of science, technology and humanity taxpayers have a strong sense of the value of life, a deep understanding of death and help the family in their priority needs. 
On the other hand, waiting for the person in critical condition, to define its destination after being stabilized hemodynamically, it is a "time of uncertainty" even if the stay is long and live in an environment away from their loved ones and his work with health professionals who often see it as "a disease" by reducing its shares to the shift handover, control of vital signs, review of the transcript, administration of prescribed treatment, execution ofinvasive procedures and drawing up nursing notes; generating a science without conscience, where the nurse and the person objects health-disease process become as the high approaches or is derived from another department the opportunity to find out more about her and her overall context was lost.

Caring for a person includes an art that spans a deep anthropological wisdom, ethics and estética ${ }^{3}$. Aspects that strengthen the foundation for the theory and practice of care giving new directions to adapt it to the requirements that demand the health status of the population and society in general. 